\title{
Electrochemical Study of Diphenyl Ether Derivatives Used as Herbicides
}

\author{
Amira Zaouak, ${ }^{1}$ Fatma Matoussi, ${ }^{2}$ and Mohamed Dachraoui ${ }^{1}$ \\ ${ }^{1}$ Laboratoire de Chimie Analytique et d'Electrochimie, Département de Chimie, Faculté des Sciences de Tunis, Campus Universitaire, \\ El Manar 2, Tunis 2092, Tunisia \\ ${ }^{2}$ Département de Génie Chimique et Biologique, Institut National des Sciences Appliquées et de Technologie, Centre Urbain Nord, \\ BP 676, Tunis cedex 1080, Tunisia
}

Correspondence should be addressed to Fatma Matoussi, fatma.matoussi@insat.rnu.tn

Received 21 October 2010; Revised 24 February 2011; Accepted 25 February 2011

Academic Editor: Miloslav Pravda

Copyright () 2011 Amira Zaouak et al. This is an open access article distributed under the Creative Commons Attribution License, which permits unrestricted use, distribution, and reproduction in any medium, provided the original work is properly cited.

The electrochemical behaviour of five nitro diphenyl ethers used as herbicides is investigated in acetonitrile. A detailed study by cyclic voltammetry and exhaustive electrolysis is carried out for the anodic oxidation of 2-Chloro-6-nitro-3-phenoxyaniline (aclonifen) and shows that the major oxidation product is a dimeric compound. A mechanistic scheme involving a coupling process is postulated for the electrochemical oxidation of this compound. Furthermore, the use of differential pulse voltammetry on a glassy carbon electrode permits the selective determination of aclonifen. The limit of detection is $0.6 \mu \mathrm{g} / \mathrm{mL}$.

\section{Introduction}

The nitro diphenyl ethers (NDPEs) are commonly used as herbicides. The environmental contamination with these toxic molecules incited a number of studies concerning their occurrence and determination in various matrixes such as environmental waters and food by means of chromatography and related techniques [1-15]. The number of electrochemical studies concerning the NDPE derivatives are less numerous, even if the electrochemical approach is known to be effective both for analysis and destroying of various toxic compounds [16-20].

This paper reports the electrochemical behaviour of a series of p-nitro diphenyl ether derivatives: aclonifen, bifen$o x$, acifluorfen, nitrofen, and 4-nitro diphenyl ether parent compound. Scheme 1 presents the chemical structures of the selected molecules which are considered as multi-target herbicides.

The corresponding chemical structures cumulate various functions presuming some electroactivity. Thus, the nitro aromatic functional group is reducible with a characteristic cathodic wave. This has been observed in protic and aprotic media for bifenox and nitrofen [21,22]. The present investigation is focused on the anodic behaviour of the concerned
NDPE derivatives. This has not been described in the literature. A detailed study is performed in the case of aclonifen using cyclic voltammetry and exhaustive electrolysis. The results allow proposing a mechanistic scheme for its anodic oxidation. Furthermore, the anodic behaviour of aclonifen is analysed by means of differential pulse voltammetry (DPV), which is shown to be a sensitive method permitting a rapid determination of the concerned herbicides.

\section{Experimental}

2.1. Electrochemical. The electrochemical measurements are made in acetonitrile in the presence of tetrabutylammonium tetrafluoroborate $\left(\mathrm{NBu}_{4} \mathrm{BF}_{4}\right) 0.1 \mathrm{M}$ as the supporting electrolyte.

The voltammetric study is performed with a Voltalab 80 analyser from radiometer. The working electrode is a $3 \mathrm{~mm}$ diameter glassy carbon disk.

The exhaustive electrolyses are carried out at a constant potential located on the first wave. They are performed with a PTJ 35-2 potentiostat and an IG5 integrator both from Tacussel. The separated cell is equipped with a platinum grid $\left(4 \mathrm{~cm}^{2}\right)$ and a platinum wire, respectively, as the working and 
<smiles>CCCCOCCOc1ccc(Oc2ccc(Cl)cc2Cl)cc1</smiles><smiles>O=C(O)c1cc(Oc2ccc(C(F)(F)F)cc2Cl)ccc1[N+](=O)[O-]</smiles><smiles>O=[N+]([O-])c1ccc(Oc2ccc(Cl)cc2Cl)cc1</smiles>

Nitrofen

Scheme 1: Names and chemical structures of the studied nitro diphenyl ether derivatives.

the auxiliary electrode. The reference is a saturated calomel electrode (SCE). The electrolysis solutions are evaporated then extracted with chloroform before chromatographic analysis.

The differential pulse voltammetry is performed with a POL 150 radiometer analyser associated with MDE 150 stand equipped with a glassy carbon disk as the working electrode.

2.2. HPLC/MS. The electrolysis products are separated and analysed by HPLC with a C- 18 column $(150 \mathrm{~mm} \times 4.6 \mathrm{~mm}$ and $5 \mu \mathrm{m}$ particle size) at $40^{\circ} \mathrm{C}$. The mobile phase is a mixture of water/acetonitrile (40/60). A DAD detector is used. The mass spectrometric analysis is performed with an Agilent 1100 MSD triple-quadrupole in the APCI negative mode. Nitrogen is the nebulizer and the collision gas. The analysis parameters are fixed as follows: $T=400^{\circ} \mathrm{C}$; gas flow: $12 \mathrm{~L} / \mathrm{min}$; nebulizer gas pressure: $50 \mathrm{psi}$; capillary voltage: $5000 \mathrm{~V}$; corona current: $4 \mu \mathrm{A}$.

2.3. Chemical. The studied compounds: aclonifen, bifenox, acifluorfen, nitrofen, 4-nitro diphenyl ether, and the supporting electrolyte tetrabutylammonium tetrafluoroborate are from Fluka. The solvent acetonitrile (HPLC quality) is purchased from Panreac.

Aclonifen Oxidation Product. Characterisation of the main product of the electrochemical oxidation of aclonifen is achieved in the electrolysis solution using HPLC/mass spectrometry coupling, ultraviolet-visible absorption, and FTIR spectrophotometry.

(i) Mass spectrum: $m / z=524(100 \%), 526(70 \%), 528$ (10\%); 390 (5\%); 249 (3\%). The molecular cluster is composed of peaks at $\mathrm{m} / z=524,526$ and 528. This result perfectly fits the empirical formula $\mathrm{C}_{24} \mathrm{H}_{14} \mathrm{Cl}_{2} \mathrm{~N}_{4} \mathrm{O}_{6}$ containing two chlorine atoms and leads to the isotopic distribution: $\mathrm{C}_{24} \mathrm{H}_{14}^{35} \mathrm{Cl}_{2} \mathrm{~N}_{4} \mathrm{O}_{6}$, $\mathrm{C}_{24} \mathrm{H}_{14}^{35} \mathrm{Cl}^{37} \mathrm{ClN}_{4} \mathrm{O}_{6}$, and $\mathrm{C}_{24} \mathrm{H}_{14}^{37} \mathrm{Cl}_{2} \mathrm{~N}_{4} \mathrm{O}_{6}$.

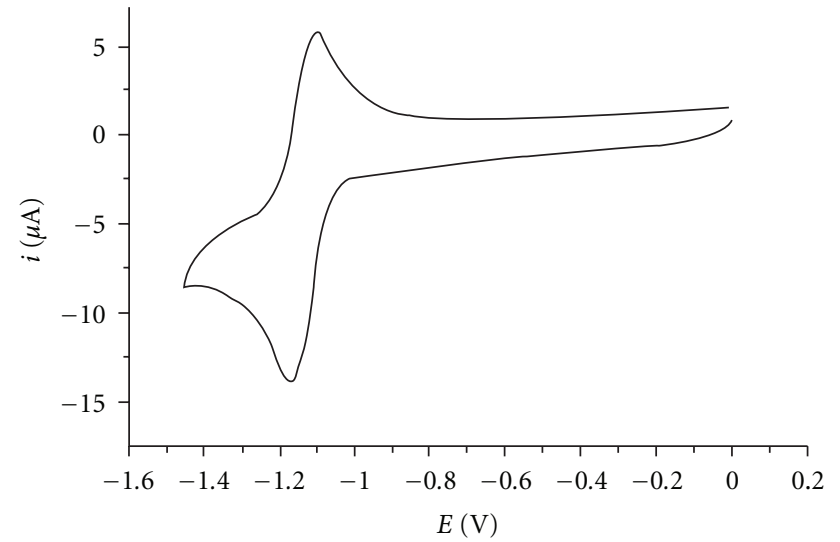

FIGURE 1: Reduction voltammogram of aclonifen. Acetonitrile, $\mathrm{NBu}_{4} \mathrm{BF}_{4} 0.1 \mathrm{M}, C=0.5 \mathrm{mM}, v=100 \mathrm{mV} \mathrm{s}^{-1}$, glassy carbon disk $(d=3 \mathrm{~mm})$, reference: SCE.

(ii) FTIR spectrum: wave number $\left(\mathrm{cm}^{-1}\right)$ : 2970-2930 (C$\mathrm{H}) ; 1444(\mathrm{~N}=\mathrm{N}) ; 1405,1376\left(\mathrm{C}-\mathrm{NO}_{2}\right) ; 1200-1250$ (C-N); 1039, 1060 (C-O); $751(\mathrm{C}-\mathrm{Cl})$.

(iii) UV-visible spectrum: $\lambda_{\max }=299 \mathrm{~nm} ; 498 \mathrm{~nm}$ $\left(>2300 \mathrm{~mol}^{-1} \mathrm{~L} \mathrm{~cm}^{-1}\right)$.

\section{Results and Discussion}

\subsection{Voltammetric Study}

3.1.1. Cathodic Reduction. The voltammetric study shows that all compounds except acifluorfen have similar cathodic behaviours. A single reversible peak is obtained as observed in Figure 1, illustrating the reduction voltammogram of aclonifen. This is attributed to the formation of a stable anion radical at the concerned time scale. The reduction peak characteristics are given in Table 1. 


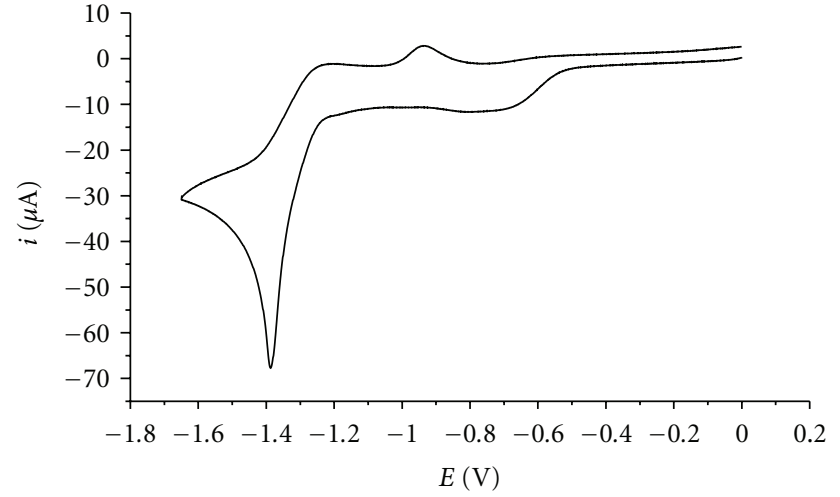

FIgURE 2: Reduction voltammogram of acifluorfen. Acetonitrile, $\mathrm{NBu}_{4} \mathrm{BF}_{4} 0.1 \mathrm{M}, C=2 \mathrm{mM}, v=100 \mathrm{mV} \mathrm{s}^{-1}$, glassy carbon disk $(d=3 \mathrm{~mm})$, reference: SCE.

TABLE 1: Reduction of nitro diphenyl ether derivatives. Acetonitrile, $\mathrm{NBu}_{4} \mathrm{BF}_{4} 0.1 \mathrm{M}, \mathrm{C}=1 \mathrm{mM}, v=100 \mathrm{mV} \mathrm{s}^{-1}$, glassy carbon disk $(d=3 \mathrm{~mm})$, reference: SCE.

\begin{tabular}{lcc}
\hline Compounds & $E_{\mathrm{pc}}(\mathrm{V})$ & $\Delta E_{p}(\mathrm{mV})$ \\
\hline Aclonifen & -1.165 & 0.062 \\
Bifenox & -1.031 & 0.057 \\
nitrofen & -1.446 & 0.063 \\
4 Nitro DPE & -1.606 & 0.061 \\
Acifluorfen & -1.384 & $*$ \\
\hline
\end{tabular}

$E_{\mathrm{pc}}$ : cathodic peak potential; $\Delta E_{p}$ : width of the reversible. cathodic peak. $*$ irreversible peak.

It appears that the electrochemical reversibility is not affected by the substitution of the nitroaromatic ring by various groups such as $\mathrm{Cl}, \mathrm{NH}_{2}, \mathrm{CO}_{2} \mathrm{H}$, and $\mathrm{COOCH}_{3}$, whereas in the same time, the reduction potential is noticeably modified.

Acifluorfen behaves in a different manner as shown in Figure 2. The cyclic voltammogram involves two cathodic peaks, both irreversible. The first one is a "plateau"-shaped monoelectronic wave. The second peak corresponds to the exchange of approximately 3 electrons. Thus, the presence of an acidic group neighbouring the nitro functional group induces very probably an intramolecular deactivation of the anion radical.

3.1.2. Anodic Oxidation. The oxidation voltammograms of the studied compounds have a rather similar pattern. The obtained anodic peaks do not show any reversibility on the reverse scan. The corresponding data are given in Table 2 . They show that the studied diphenyl ether derivatives are oxidized at potentials superior to $1650 \mathrm{mV} / \mathrm{SCE}$. In addition, for all compounds, excepted aclonifen, the current peak is high and implies the exchange of an important number of electrons. The corresponding $n_{\mathrm{e}}$ values are obtained by calculating the current ratio $i_{\mathrm{Pa}} / i_{\mathrm{Pc}}, i_{\mathrm{Pa}}$, and $i_{\mathrm{Pc}}$ are, respectively, the oxidation and reversible reduction peak currents. The obtained high values suggest that the anodic oxidation of diphenyl ether derivatives proceeds
TABLe 2: Oxidation of nitro diphenyl ether derivatives. Acetonitrile, $\mathrm{NBu}_{4} \mathrm{BF}_{4} 0.1 \mathrm{M}, C=1 \mathrm{mM}, v=100 \mathrm{mV} \mathrm{s}^{-1}$, glassy carbon disk $(d=3 \mathrm{~mm})$, reference: SCE.

\begin{tabular}{lcc}
\hline Compounds & $E_{\mathrm{pa}}(\mathrm{V})$ & $n_{\mathrm{e}}$ \\
\hline Aclonifen & 1.714 & 2.2 \\
Nitrofen & 1.924 & 4.2 \\
Bifenox & 2.237 & 4.3 \\
4 nitro DPE & 1.649 & 4.3 \\
Acifluorfen & 2.531 & 3.3 \\
\hline
\end{tabular}

$E_{\mathrm{pa}}$ : anodic peak potential;

$n_{\mathrm{e}}$ : number of exchanged electrons

via a complex mechanism. Several electron transfers and associated chemical reactions are involved. In fact, further information is required for clarifying the anodic process. This concerns especially the oxidation products.

In the following, we report the more detailed investigation concerning the electrochemical oxidation of aclonifen. The study is performed at the voltammetric and exhaustive electrolysis scales.

As observed in Figure 3, the oxidation voltammogram of aclonifen exhibits two anodic peaks. The first one is well defined and the corresponding number of electrons exchanged per mole is close to 2 .

Furthermore, the peak potential variation as a function of the scan rate gives a linear $E_{p}=f(\log v)$ graph, the slope is approximately $30 \mathrm{mV}$ (Figure 4 ). We notice that the concentration does not affect the $E_{p}$ value. These results are consistent with an ECE type mechanism, the chemical step being a first-order deactivation of the cation radical ensuing the first electron transfer.

3.2. Exhaustive Electrolysis. The exhaustive electrolyses of aclonifen are carried out at a constant potential $(E=$ $1.7 \mathrm{~V} / \mathrm{SCE})$ located at the first anodic peak. They are stopped after the consumption of $2 \mathrm{~F} /$ mole. The HPLCmass spectrometric analysis of the electrolysis solution shows that the major oxidation product is a dimeric compound deriving from the starting material. The molecular weight is around 524. Furthermore, the mass spectrum given in the experimental section shows a molecular cluster at $\mathrm{m} / \mathrm{z}$ : $524(100 \%), 526(70 \%)$, and $528(13 \%)$ compatible with the presence of two chlorine atoms. The peak at $\mathrm{m} / \mathrm{z}=249$ is probably due to the elimination of a nitrogen molecule from the molecular ion of the azo compound which derives from aclonifen (Scheme 2).

The proposed chemical structure is supported by the spectrometric analysis in UV-visible range. Actually, a significant absorption is observed at $498 \mathrm{~nm}$, which may be attributed favourably to a nitrogen double bond of a substituted azobenzene. Moreover, when comparing the FTIR spectrum of the electrolysis solution to that of aclonifen, there is a new band located at $1444 \mathrm{~cm}^{-1}$ which can be attributed to the $\mathrm{N}=\mathrm{N}$. These results suggest that dimerization is the predominant pathway in the anodic oxidation of aclonifen. It is worth noticing that this type of oxidative coupling has been described in the literature for 
<smiles>O=[N+]([O-])c1ccc(Oc2ccccc2)c(Cl)c1/N=N/c1c([N+](=O)[O-])ccc(Oc2ccccc2)c1Cl</smiles>

Scheme 2: chemical structure of the major oxidation product of aclonifen.<smiles>Nc1c([N+](=O)[O-])ccc(O[Al])c1Cl</smiles>

(I)<smiles>Nc1c([N+](=O)[O-])ccc(O[Al])c1Cl</smiles>

(II)<smiles>O=[N+]([O-])c1ccc(O[Al])c([N+](=O)[O-])c1N=Nc1c([14Cl])ccc(O[Al])c1Cl</smiles><smiles>O=[N+]([O-])c1ccc(O[Al])c(Cl)c1NNc1c([N+](=O)[O-])ccc(O[Al])c1Cl</smiles>

Scheme 3: Mechanism of the anodic oxidation of aclonifen $\mathrm{Ar}: \mathrm{C}_{6} \mathrm{H}_{5}$.

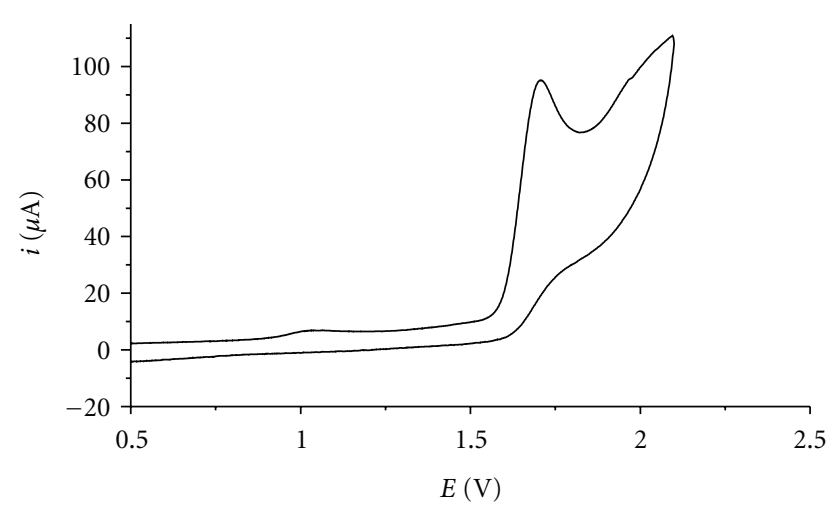

FIgURE 3: Oxidation voltammogram of aclonifen. Acetonitrile, $\mathrm{NBu}_{4} \mathrm{BF}_{4} 0.1 \mathrm{M}, C=3 \mathrm{mM}, v=20 \mathrm{mV} \mathrm{s}^{-1}$, glassy carbon disk $(d=3 \mathrm{~mm})$, reference: SCE.

aromatic amine such as aniline and its derivatives, which are oxidized in the well-known polyaniline conducting polymer. For aclonifen, the ultimate oxidation product being an azo dimeric compound, the amino group is likely the preferred site for electron uptake and coupling. This explains why

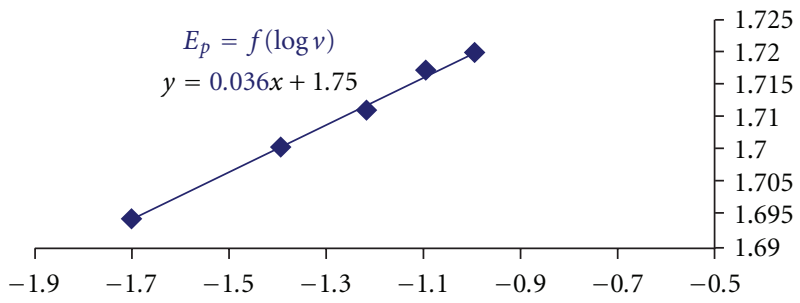

Figure 4: Aclonifen potential peak variation with scan rate $C=$ $2 \mathrm{mM}$, reference: SCE.

the polymerization process is not actually observed. Thus, the mechanistic scheme of aclonifen oxidation involves very probably the steps given in Scheme 3. It accounts for the voltammetric, preparative, and coulometric results.

The cation radical (I) ensuing the first electron transfer is deprotonated in a rate determining step. The resulting radical (II) undergoes a rapid dimerisation and gives the intermediate (III), which is oxidized and deprotonated before leading to the final azo compound. 


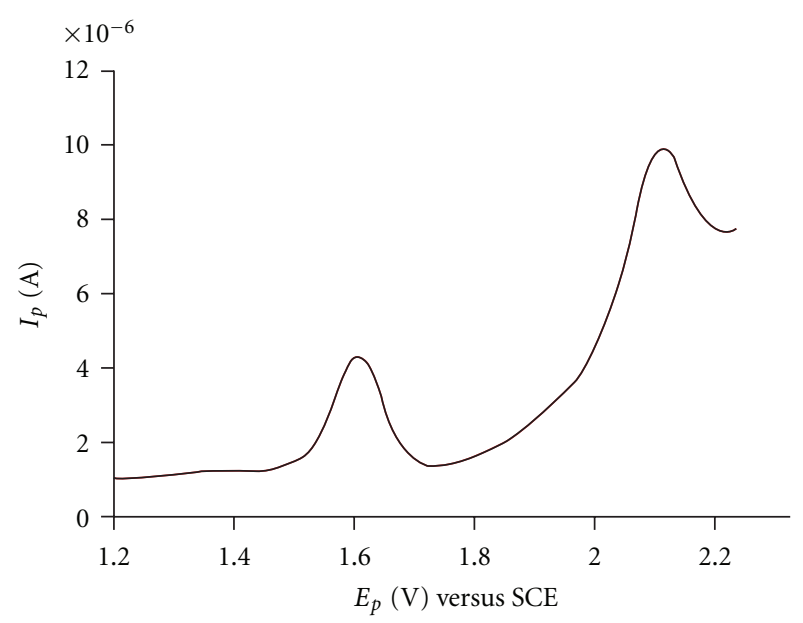

Figure 5: Differential pulse voltammogram of aclonifen. $(C=$ $15 \mathrm{ppm})$ and bifenox $(C=15 \mathrm{ppm})$. Acetonitrile, $\mathrm{Bu}_{4} \mathrm{NBF}_{4}(0.1 \mathrm{M})$, glassy carbon $(d=3 \mathrm{~mm})$; scan rate: $5 \mathrm{mV} \mathrm{s}^{-1}$; pulse amplitude $=$ $50 \mathrm{mV}$; pulse width: $20 \mathrm{~ms}$.

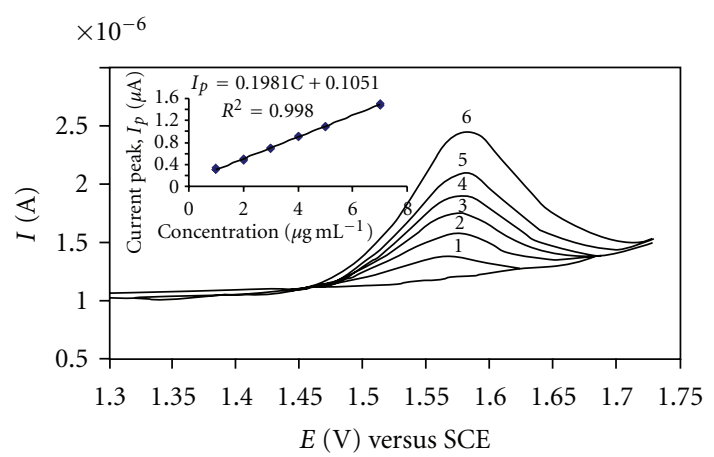

Figure 6: Differential pulse voltammograms of aclonifen in acetonitrile, $\mathrm{Bu}_{4} \mathrm{NBF}_{4}(0.1 \mathrm{M})$, glassy carbon $(d=3 \mathrm{~mm})$; scan rate: $5 \mathrm{mV} \mathrm{s}^{-1}$; pulse amplitude $=50 \mathrm{mV}$; pulse width: $20 \mathrm{~ms} . C=1-$ $7 \mu \mathrm{g} / \mathrm{mL}$.

\section{Analysis of Aclonifen Using Differential Pulse Voltammetry (DPV)}

The results of the above electrochemical study of several herbicides can be used for their electrochemical determination. The present section concerns the determination of aclonifen by differential pulse voltammetry. The DPV analysis is preferred to cyclic voltammetry for quantification, since the developed peaks are better defined. The DPV anodic voltammogram on a glassy carbon electrode of aclonifen in the presence of bifenox is given in Figure 5.

Thus, a selective determination of aclonifen is possible in natural matrix containing both compounds. Figure 6 illustrates the DPV voltammograms obtained with aclonifen concentrations comprised in the range: $1-7 \mu \mathrm{g} / \mathrm{mL}$.

The calibration plot of the peak current versus the concentration is linear $\left(R^{2}=0.998\right)$. The limit of detection (LOD) and the limit of quantification (LOQ) calculated according to the XTP 90-210 standard are, respectively, 0.6 and $0.8 \mu \mathrm{g} / \mathrm{mL}$.

\section{Conclusion}

The electrochemical behaviour of five nitro diphenyl ether derivatives used as herbicides is investigated in acetonitrile on a glassy carbon electrode. On one hand, the cathodic reduction leads to the corresponding anion radical which is stable at the voltammetric scale, except acifluorfen which gives an irreversible cathodic peak. This is due probably to an intramolecular protonation of the nitroaromatic anion radical by the neighbouring acidic group. On the other hand, the studied herbicides give irreversible oxidation peaks. The number of exchanged electrons is superior to 2 except for aclonifen. A detailed study carried out for this compound shows that the predominant oxidation process involves a coupling step. Indeed the major oxidation product is an azo dimeric compound. A mechanistic scheme accounting for this result is proposed.

Furthermore, this electrochemical study shows that differential pulse voltammetry on a glassy carbon electrode is effective in the selective determination of aclonifen in the presence of bifenox. The corresponding limits of detection and quantification are obtained.

\section{Acknowledgments}

This work has been achieved with the financial support of the Ministère de l'Enseignemnt Supèrieur et de la Recherche Scientifique (Tunisia). The authors thank Pr. L. Monser for proofreading and Dr. F. Oueslati for mass spectrometric analysis.

\section{References}

[1] L. Guzzella, F. Pozzoni, and G. Giuliano, "Herbicide contamination of surficial groundwater in Northern Italy," Environmental Pollution, vol. 142, no. 2, pp. 344-353, 2006.

[2] K. Carbery, R. Owen, T. Frickers, E. Otero, and J. Readman, "Contamination of Caribbean coastal waters by the antifouling herbicide Irgarol 1051," Marine Pollution Bulletin, vol. 52, no. 6, pp. 635-644, 2006.

[3] C. H. Pickett, L. S. Hawkins, J. E. Pehrson, and N. V. O'Connell, "Irrigation practices, herbicide use and groundwater contamination in citrus production: a case study in California," Agriculture, Ecosystems and Environment, vol. 41, no. 1, pp. 1-17, 1992.

[4] A. Laganà, A. Bacaloni, I. De Leva, A. Faberi, G. Fago, and A. Marino, "Occurrence and determination of herbicides and their major transformation products in environmental waters," Analytica Chimica Acta, vol. 462, no. 2, pp. 187-198, 2002.

[5] C. Vischetti, C. Marucchini, L. Leita, P. Cantone, F. Danuso, and R. Giovanardi, "Behaviour of two sunflower herbicides (metobromuron, aclonifen) in soil," European Journal of Agronomy, vol. 16, no. 3, pp. 231-238, 2002.

[6] C. O. Martinez, C. M. M. S. Silva, E. F. Fay, A. D. H. Nunes Maia, R. B. Abakerli, and L. R. Durrant, "Degradation of the herbicide sulfentrazone in a Brazilian Typic Hapludox 
soil," Soil Biology and Biochemistry, vol. 40, no. 4, pp. 853-860, 2008.

[7] G. R. Leather and C. L. Foy, "Metabolism of bifenox in soil and plants," Pesticide Biochemistry and Physiology, vol. 7, no. 5, pp. 437-442, 1977.

[8] S. Chiron, S. Papilloud, W. Haerdi, and D. Barceló, "Automated on-line liquid-solid extraction followed by liquid chromatography-High-flow pneumatically assisted electrospray mass spectrometry for the determination of acidic herbicides in environmental waters," Analytical Chemistry, vol. 67, no. 9, pp. 1637-1643, 1995.

[9] M. A. Aramendía, V. Borau, F. Lafont et al., "Determination of herbicide residues in olive oil by gas chromatography-tandem mass spectrometry," Food Chemistry, vol. 105, no. 2, pp. 855861, 2007.

[10] R. Curini, A. Gentili, S. Marchese, A. Marino, and D. Perret, "Solid-phase extraction followed by high-performance liquid chromatography-ionspray interface-mass spectrometry for monitoring of herbicides in environmental water," Journal of Chromatography A, vol. 874, no. 2, pp. 187-198, 2000.

[11] A. Laganà, G. Fago, L. Fasciani, A. Marino, and M. Mosso, "Determination of diphenyl-ether herbicides and metabolites in natural waters using high-performance liquid chromatography with diode array tandem mass spectrometric detection," Analytica Chimica Acta, vol. 414, no. 1-2, pp. 79-94, 2000.

[12] A. Tanabe, H. Mitobe, K. Kawata, and M. Sakai, "Monitoring of herbicides in river water by gas chromatography-mass spectrometry and solid-phase extraction," Journal of Chromatography A, vol. 754, no. 1-2, pp. 159-168, 1996.

[13] A. Laganà, G. Fago, A. Marino, and V. M. Penazzi, "Liquid chromatography mass spectrometry tandem for multiresidue determination of selected post-emergence herbicides after soil column extraction," Analytica Chimica Acta, vol. 415, no. 1-2, pp. 41-56, 2000.

[14] V. Andreu and Y. Picó, "Determination of pesticides and their degradation products in soil: critical review and comparison of methods," Trends in Analytical Chemistry, vol. 23, no. 1011, pp. 772-789, 2004.

[15] K. Ridgway, S. P. D. Lalljie, and R. M. Smith, "Sample preparation techniques for the determination of trace residues and contaminants in foods," Journal of Chromatography A, vol. 1153, no. 1-2, pp. 36-53, 2007.

[16] E. Manuela Garrido, J. L. Costa Lima, C. M. Delerue-Matos C., and A. Maria Oliveira Brett, "Electrochemical oxidation of bentazon at a glassy carbon electrode: application to the determination of a commercial herbicide," Talanta, vol. 46, no. 5, pp. 1131-1135, 1998.

[17] M. Pedrero, R. Gálvez, E. Rodríguez, F. J. Manuel De Villena, and J. M. Pingarrón, "Determination of the herbicide desmetryne in organised media by adsorptive stripping voltammetry," Talanta, vol. 53, no. 5, pp. 991-1000, 2001.

[18] T. Sarigül and R. Inam, "Study and determination of the herbicide cyclosulfamuron by square wave stripping voltammetry," Electrochimica Acta, vol. 54, no. 23, pp. 5376-5380, 2009.

[19] C. Fernandez, A. J. Reviejo, and J. M. Pingarron, "Development of graphite-poly(tetrafluoroethylene) composite electrodes. Voltammetric determination of the herbicides thiram and disulfiram," Analytica Chimica Acta, vol. 305, no. 1-3, pp. 192-199, 1995.

[20] M. A. E. Mhammedi, M. Bakasse, and A. Chtaini, "Electrochemical studies and square wave voltammetry of paraquat at natural phosphate modified carbon paste electrode," Journal of Hazardous Materials, vol. 145, no. 1-2, pp. 1-7, 2007.
[21] G. L. Orr, C. M. Elliott, and M. E. Hogan, "Electrochemical characterization and redox reaction scheme of the diphenyl ether herbicide nitrofen," Pesticide Biochemistry and Physiology, vol. 21, no. 2, pp. 242-247, 1984.

[22] M. Hromadová, P. Mořkovská, L. Pospíšil, and S. Giannarelli, "Decomposition reactions of bifenox anion radical involving intramolecular electron transfer," Journal of Electroanalytical Chemistry, vol. 582, no. 1-2, pp. 156-164, 2005. 


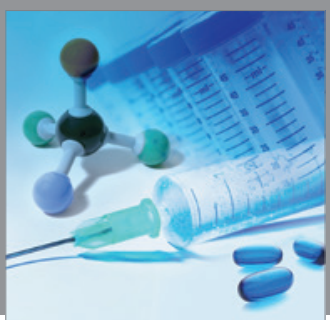

International Journal of

Medicinal Chemistry

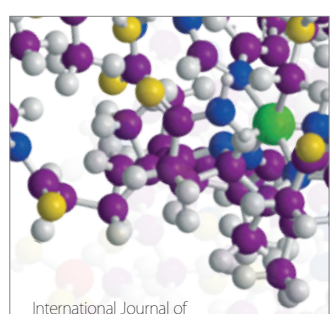

Carbohydrate Chemistry

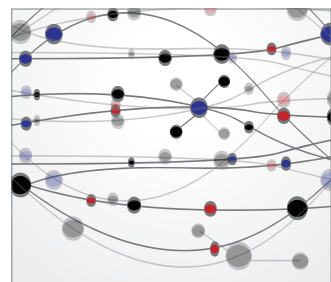

The Scientific World Journal
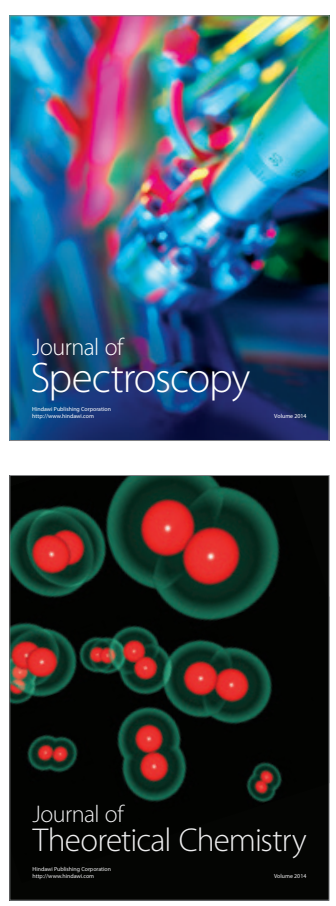
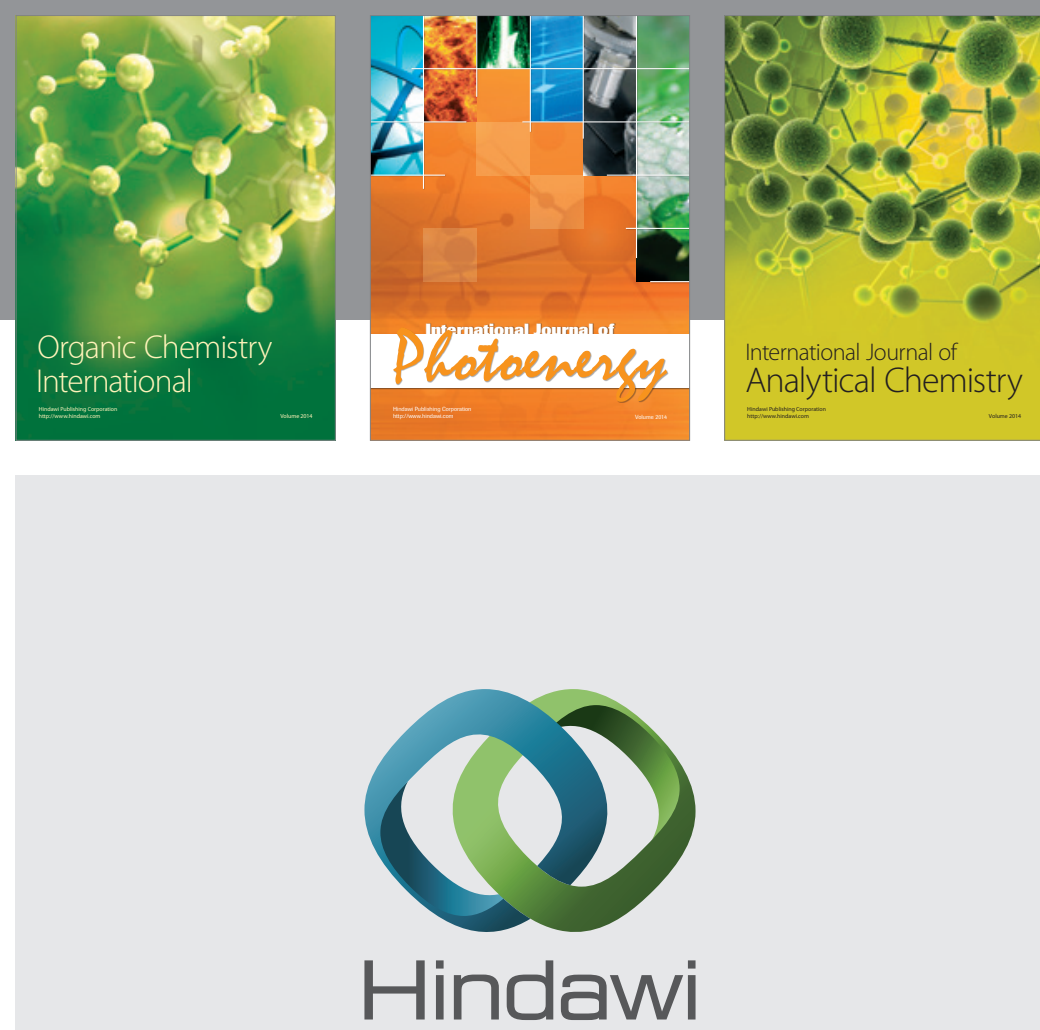

Submit your manuscripts at

http://www.hindawi.com
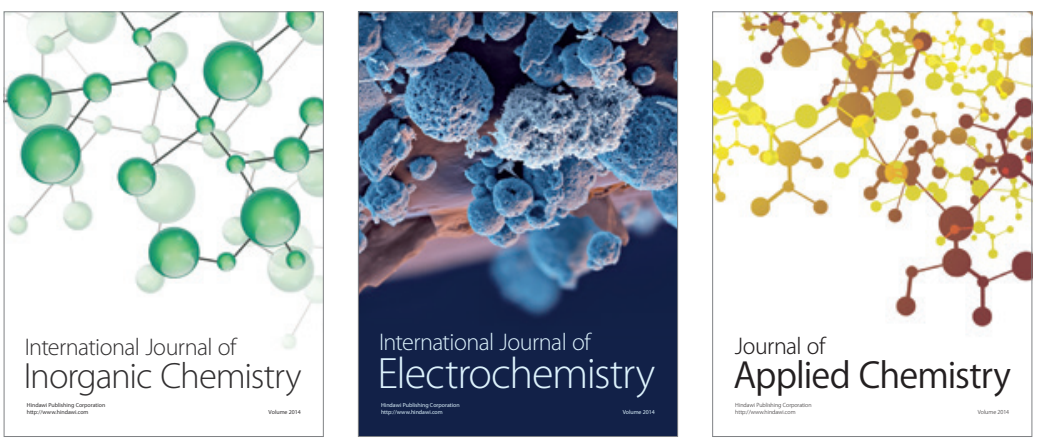

Journal of

Applied Chemistry
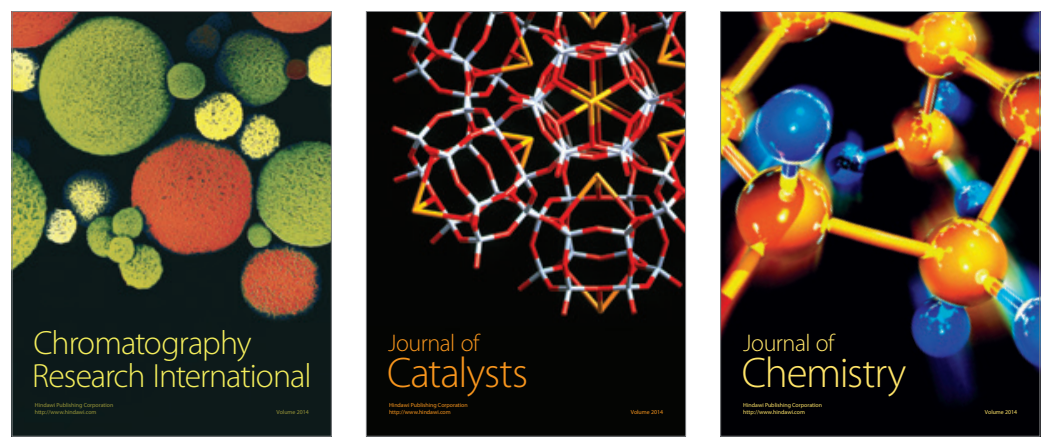
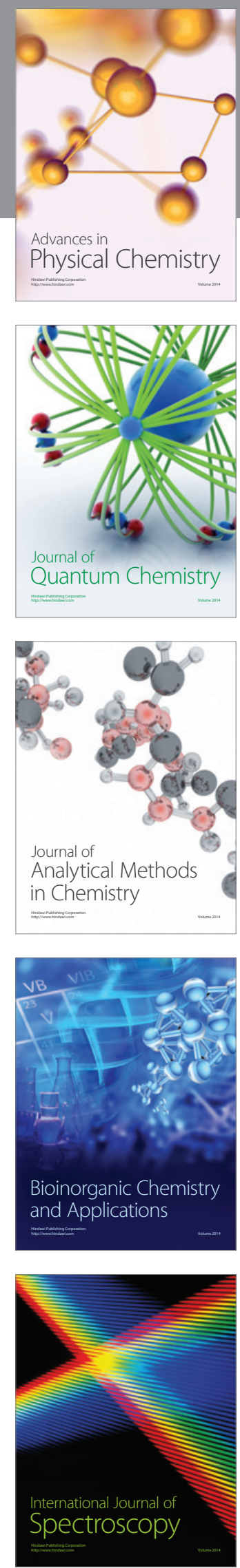